\title{
Cacao in Mexico: Restrictive factors and productivity levels
}

\author{
Julio Díaz-José1, Oscar Díaz-José2 ${ }^{*}$, Saturnino Mora-Flores ${ }^{3}$, Roberto Rendón-Medel ${ }^{4}$, \\ and Ricardo Tellez-Delgado ${ }^{3}$
}

Cacao (Theobroma cacao L.) represents one of the most important agricultural crops of the humid Mexican tropics. In the last $10 \mathrm{yr}$, approximately $23000 \mathrm{t}$ of this grain were no longer produced per cycle. The objective of this study was to identify characteristics and factors that restrict production in the states of Tabasco and Chiapas. A survey was applied to obtain information about 184 producers and their plantations by two-stage sampling. Descriptive statistics were calculated and multilevel models were adjusted to analyze the information. Results show that there are differences $(P<0.05)$ in cacao yield between municipalities (380 $\mathrm{kg} \mathrm{ha}^{-1}+\mu_{\mathrm{oj}}$ is the estimated residual for each municipality). Crop productivity levels are higher in the state of Tabasco than in Chiapas (644 and $344 \mathrm{~kg} \mathrm{ha}^{-1}$, respectively). Incidence of frosty pod rot of cacoa, also known as moniliasis, induced by Moniliophthora roreri [(Cif) H.C. Evans, Stalpers, Samson \& Benny 1978] is significantly greater $(P<0.05)$ in the state of Chiapas $(60 \%)$ than in Tabasco $(48 \%)$.Producers who carry out more crop management practices increase yields and decrease the pathogen's impact on their plantations. Results suggest the need to apply differentiated public policies to promote production within each region or municipality.

Key words: Cocoa production, Moniliophthora roreri, multilevel analysis, Theobroma cacao.

\section{INTRODUCTION}

Cacao (Theobroma cacao L.) is one of the most important agricultural and cultural products of the Mexican humid tropics. This crop is grown in 61344 ha distributed mainly in the states of Tabasco (68.2\%) and Chiapas (31.2\%) and is a source of income for nearly 41000 families (SIAP, 2012). According to the Tax Information System (Sistema de Información Arancelaria, 2012), Mexico imported 39240 t in 2010 primarily from Ecuador, Ivory Coast, Indonesia, and the Dominican Republic.

During the period from 2000 to 2010 , cacao production in Mexico decreased drastically from 49 to $27000 \mathrm{t}$, which represents a mean annual growth rate (MAGR) of $-8.3 \%$. This indicates that nearly $23000 \mathrm{t}$ of cacao are

${ }^{1}$ Cornell International Institute for Food Agriculture and Development (CIIFAD), Cornell University, B75 Mann Library, 14853, Ithaca, New York, USA.

${ }^{2}$ Consejo Mexiquense de Ciencia y Tecnología (COMECYT), Hacienda Cieneguilla 1, esq. Hacienda Jurica, Colonia Sta. Elena, San Mateo Atenco, Estado de México, México. C.P. 52100. *Corresponding author (oscardiazjose@gmail.com).

${ }^{3}$ Colegio de Postgraduados, Economía, 56230. Montecillo, Estado de México, México.

${ }^{4}$ Universidad Autónoma Chapingo, Centro de Investigaciones Económicas, Sociales y Tecnológicas de la Agroindustria y la Agricultura Mundial (CIESTAAM), Carretera México-Texcoco km 38.5, 56230 Chapingo, México.

Received: 19 September 2013.

Accepted: 15 July 2014

doi:10.4067/S0718-58392014000400004 no longer produced. The main factors associated with the decrease in production are: a) presence of moniliasis (MO) Moniliophthora roreri [(Cif) H.C. Evans, Stalpers, Samson \& Benny 1978] detected in 2005, which significantly affects yield (Phillips-Mora et al., 2006; 2007) and is considered as the most dangerous cacao disease (ten Hoopen et al., 2012); b) abandonment of plantations motivated by low profitability in many of the production zones of Tabasco and Chiapas (Ogata, 2007); and c) competitive disadvantages in the international market (González, 2005).

Studies about cacao cultivation have been carried out in Mexico in recent years; these are mainly focused on disease management (Phillips-Mora et al., 2007; CuervoParra et al., 2011; Torres de la Cruz et al., 2011) and on identifying factors that affect plantation productivity and productive systems (Córdova et al., 2001; ZamarripaColmenero et al., 2011; Hernández-Gómez et al., 2012). These local studies contribute important information about productive technical aspects; however, they do not give a general vision of the activity as a whole.

The objective of this study was to identify the general characteristics of cacao producers and their plantations, as well as the restrictive factors that affect yield. The latter had the aim of contributing information for generating intervention strategies to promote production.

The general hypothesis suggested that there are differences in productivity levels between Tabasco and Chiapas associated with biotic and abiotic factors, and that crop management practices can control dispersion of the disease. 


\section{MATERIALS AND METHODS}

Information was obtained by applying a survey to producers in Tabasco and Chiapas; sampling was carried out in two stages from the cacao producer census. To calculate sample size, the population was divided into groups; in the first stage, primary units, municipalities, were selected by simple random sampling, and the second stage consisted in sampling each municipality with the following formula:

$$
\mathrm{n}=\mathrm{Z}^{2} \mathrm{q} \text { DEFF/ } / \mathrm{r}^{2} \mathrm{p}(1-\mathrm{tnr}) \text { PS }
$$

where $n$ is sample size, $Z$ is the value of the normal distribution, $p$ is the proportion of interest (maximum variance), $q=1$ - proportion of interest, DEFF is the design effect defined as the loss or gain in design efficiency by grouping elements of the population to form units, $r$ is the maximum expected relative error, $t n r$ is the rate of expected non-maximum response, and $P S$ $=N / N_{i}$ is the municipal proportion of rural production units recorded in the producer census where $N$ is the total number of secondary units in the population $(30000)$ producers and $N_{i}$ is the number of secondary units in the selected municipality. Sample size was 184 producers (136 in Tabasco and 48 in Chiapas). A questionnaire consisting of three sections was applied: a) information related to general producer attributes (age, education, land ownership), b) characteristics of cacao plantations (yield, crop association, area, age of plantation), and c) cultivation and marketing practices (plague and disease control, pruning, input purchase, cacao sales).

Statistical analysis of producer data was performed with multilevel models which adjust models of hierarchical or nested data. According to Hox (2002), analyzing variables that have different levels as if they had only one level is not adequate for two reasons: a) the first is of a statistical nature because they lose information and power; and $b$ ) the second is conceptual since data are analyzed at one level and sometimes conclusions are formulated at a different level. For theoretical discussion and development, see De Leeuw and Meijer (2008) and Snijders (2011). In the present study, a two-level model was applied; producers generated the first level and municipalities the second (Figure 1).

Regarding data analysis, statistics were calculated and a multilevel regression analysis was performed with the $\mathrm{R}$ statistical package. Multilevel analysis is a step-bystep process (Steele, 2008) that stems from a simple null regression model that later adjusts more complex models. The present study included three phases. The first phase

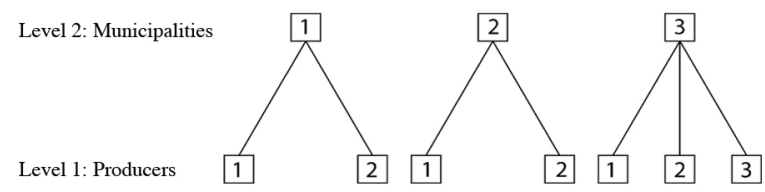

Figure 1. Cacao producers nested in municipalities: Two-level model. consisted in calculating differences in cacao yield between municipalities and within municipalities. This is based on a simple null model [2].

$$
y_{i j}=\beta_{o}+e_{i j}
$$

In the two-level model the residual is divided into two components, which correspond to each level in the data structure (3). The multilevel null model is expressed in Equation [3].

$$
\mathrm{y}_{\mathrm{ij}}=\beta_{\mathrm{o}}+\mu_{\mathrm{oj}}+\mathrm{e}_{\mathrm{ij}}
$$

where $y_{i j}$ is the cacao yield of producer $i$ in municipality $j, \beta_{o}$ is the overall yield mean in the municipalities (all groups), $\mu_{o j}$ is the effect of municipality $j$ on yield, and $e_{i j}$ is each producer's residual (difference between the y-value for the $\mathrm{i}^{\text {th }}$ individual and that individual's group mean). The variance between municipalities $\sigma_{u}^{2}($ level 2) and the variance between producers $\sigma_{\mathrm{e}}^{2}$ (level 1) were obtained by equation [3]. The variance partition coefficient (VPC) was calculated to measure the proportion of total variance that is explained by differences between groups, expressed in Equation [4].

$$
\mathrm{VPC}=\varrho=\sigma_{\mathrm{u}}^{2} / \sigma_{\mathrm{u}}^{2}+\sigma_{\mathrm{e}}^{2}
$$

To compare groups in level 2, estimators were obtained for $\mu_{j}$ for each municipality with the Equation [5a]:

$$
\mu_{\mathrm{j}}=\mathrm{w} \overline{\mathrm{e}}_{\mathrm{j}}
$$

where $\bar{e}_{j}$ is the mean residual for each group $j$, expressed in Equation [5b]:

$$
\overline{\mathrm{e}}_{\mathrm{j}}=\overline{\mathrm{y}}_{\mathrm{j}}-\hat{\beta}_{0}
$$

The estimator $w$ expresses the shrunken residuals or Empirical Bayes Estimates in Equation [5c]:

$$
\mathrm{w}=\sigma^{2}{ }_{\mathrm{u}} / \sigma^{2}{ }_{\mathrm{u}}+\left(\sigma^{2} \mathrm{e} / \mathrm{n}_{\mathrm{j}}\right)
$$

Residues at the producer $e_{i j}$ level are the predictions and they were obtained as expressed in Equation [5d]:

$$
\overline{\mathrm{e}}_{\mathrm{ij}}=\mathrm{e}_{\mathrm{ij}}-\mathrm{u}_{\mathrm{j}}=\mathrm{y}_{\mathrm{ij}}-\bar{\beta}_{0}-\bar{\mu}_{\mathrm{j}}
$$

To test the null hypothesis that there are no group differences $\left(H o: \sigma^{2}{ }_{u}=0\right)$ by comparing the null [2] and multilevel [3] models in a likelihood ratio test, a comparison test was performed by the following equation

$$
\mathrm{LR}=-2 \log \mathrm{L}_{1}-\left(-2 \log \mathrm{L}_{2}\right)
$$

where $L_{1}$ and $L_{2}$ are likelihood values of the single and multilevel models and $\log$ is the natural logarithm. Rejection of $\mathrm{Ho}$ implies that there are real group differences.

In the second phase, a multilevel random intercept model was adjusted to identify the variables that affect cacao yield. When adding a $X_{i j}$ covariable to Equation [3] at the cacao producer level, the model was specified according to Equation [7]:

$$
\mathrm{y}_{\mathrm{ij}}=\beta_{0}+\beta_{1} \mathrm{X}_{\mathrm{ij}}+\mu_{\mathrm{j}}+\mathrm{e}_{\mathrm{ij}}
$$

The overall relationship between $y$ and $X$ in this model is represented by a straight line with $\beta_{0}$ intercept and $\beta_{1}$ slope; however, the intercept for a given group $j$ is $\beta_{0}+\mu_{j}$. A multilevel model of this type consists of two components, a fixed part that specifies the relationships between the mean of $y$ and the explanatory variables and a random part that contains the residuals at levels $1\left(e_{i j}\right)$ and $2\left(\mu_{j}\right)$. In Equation [7], the fixed component is $\beta_{0}+$ 
$\beta_{1} X_{i j}$ with the fixed parameters $\beta_{0}$ and $\beta_{1}$, and the random component is $\mu_{j}+e_{i j}$ with the random parameters $\sigma^{2}{ }_{u}$ and $\sigma^{2}$. The intercept of the group regression lines is allowed to vary randomly across groups; the model then tends to be written in the form of two equations, as in Equation [8]:

$$
\begin{aligned}
& \mathrm{y}_{\mathrm{ij}}=\beta_{\mathrm{oj}}+\beta_{1} X_{\mathrm{j}}+\beta_{2} X_{\mathrm{ij}}+\beta_{3} X_{\mathrm{ij}}+\beta_{4} X_{\mathrm{ij}}+\beta_{5} X_{\mathrm{ij}}+\mathrm{e}_{\mathrm{ij}} \\
& \beta_{\mathrm{oj}}=\beta_{0}+\mu_{\mathrm{oj}} \\
& \mathrm{U}_{\mathrm{oj}} \sim \mathrm{N}\left(0, \sigma_{\mathrm{uo}}^{2}\right) \\
& \mathrm{e}_{\mathrm{ij}} \sim \mathrm{N}\left(0, \sigma_{\mathrm{e}}^{2}\right)
\end{aligned}
$$

where $y_{i j}$ is the mean cacao yield of a producer $i$ in municipality $j, \beta_{1} X_{j}$ is the incidence of $\mathrm{MO}, \beta_{2} X_{i j}$ is the relative humidity, $\beta_{3} X_{i j}$ is crop management practices (weed control, fertilization, pesticide application to control pests and diseases, and drain maintenance), $\beta_{4} X_{i j}$ is the age of the plantation (from 5 to $70 \mathrm{yr}$ ), and $\beta_{5} X_{i j}$ is the area of the cacao plantation.

In the third phase, the effects of agricultural practices to counteract the effects of MO can be understood. A multilevel random slope model was adjusted where the explicative variable has a different effect for each $\beta_{2 j}$ group. While in Equation [8] the relationship between $X$ and $y$ is the same for each group (slope $\beta_{1}, \beta_{2}$ is fixed), in Equation [9] the slope varies randomly across groups:

$$
\begin{aligned}
& y_{\mathrm{ij}}=\beta_{\mathrm{oj}}+\beta_{1} \mathrm{X}_{\mathrm{j}}+\beta_{2 \mathrm{j}} \mathrm{X}_{\mathrm{j}}+\mathrm{e}_{\mathrm{ij}} \\
& \beta_{\mathrm{oj}}=\beta_{0}+\mu_{\mathrm{oj}} \\
& \beta_{2 \mathrm{j}}=\beta_{2}+\mu_{2 \mathrm{j}} \\
& {\left[\begin{array}{l}
\mu_{\mathrm{oj}} \\
\mu_{2 \mathrm{j}}
\end{array}\right] \sim \mathrm{N}\left(0, \Omega_{\mathrm{u}}\right): \Omega_{\mathrm{u}}=\left[\begin{array}{ll}
\sigma_{\mathrm{u} 0}^{2} & \\
\sigma_{\mathrm{u} 02} & \sigma_{\mathrm{u} 2}^{2}
\end{array}\right]} \\
& \mathrm{e}_{\mathrm{ij}} \sim \mathrm{N}\left(0, \sigma_{\mathrm{e}}^{2}\right)
\end{aligned}
$$

where $y_{i j}$ is the degree of incidence of MO in plantation $i$ in municipality $j, \beta_{I} X_{j}$ is the fixed state covariable (the producer is from Chiapas $X=0$ or from Tabasco $X=1$ ), $\beta_{2 j} X_{j}$ is the index of agricultural practices used by the producer in the plantation related to MO (maintenance pruning, pruning rehabilitation, and removal of diseased fruits). The variance of slopes between groups is $\sigma^{2}{ }_{u 2}, \sigma^{2}{ }_{u 0}$ is the variance in intercepts between groups, and $\sigma_{u 02}$ is the covariance between intercepts and slopes.

\section{RESULTS AND DISCUSSION}

\section{Characteristics of cacao producers and their plantations}

The descriptive statistics obtained show that cacao producers are approximately $60 \mathrm{yr}$ of age, have basic education, and extensive experience in managing cacao crops (Table 1). Since this is a cultivation labor-intensive crop, these characteristics condition adequate plantation management and can increase production costs through the hiring of additional labor. It has also been observed that these are determining factors in issues such as technology adoption (Gershon et al., 1985; Diederen et al., 2003). These characteristics must be considered in the design and implementation of public policies to promote cacao production.
Table 1. Descriptive statistics of cacao production in Mexico.

\begin{tabular}{lrccr}
\hline Variable & Mean & Minimum & Maximum & SD \\
\hline Age & 57.50 & 29.0 & 94.0 & 14.2 \\
Education & 4.80 & 0.0 & 19.0 & 3.5 \\
Experience & 31.30 & 2.0 & 73.0 & 13.4 \\
Age of plantation, yr & 33.20 & 5.0 & 70.0 & 12.1 \\
Area of plantation, ha & 1.75 & 0.3 & 9.0 & 1.4 \\
\hline SD: standard deviation. & & & &
\end{tabular}

On the average, the age of cacao trees in Mexico is more than $30 \mathrm{yr}$. According to Zuidema et al. (2005) and Ryan et al. (2009), the highest cacao yield is observed in plantations with young trees with a high increase in biomass; tree maturity is reached between 17 and $30 \mathrm{yr}$ (Adesimi, 1984; Edwin and Masters, 2005) when yield begins to decrease. Therefore, a better renovation and maintenance scheme is required to guarantee economic viability of producers.

With regards to the area cultivated with cacao, cacao plantations are small $(<2 \mathrm{ha})$ due to the phenomenon of property fragmentation in Mexico (Díaz-José et al., 2011). This restricts the development of the activity since there is a need for efficient organizational schemes to encourage activities promoting cacao production (access to credit, marketing, transaction costs related to inputs and products, and legal disease control) (Nyemeck et al., 2007; Eastwood et al., 2009).

Schemes that outweigh the restrictions and costs related to small-scale management should be suggested when they arise from producer and plantation characteristics. Collective action could be a determining factor without external rules affecting the ability of producers to solve their problems. Collective action, rather than producer organizations, is mentioned because the formal organization is required to gain access to credit and subsidies, and structural variables are even more disrupted because of trust and reciprocity issues (Ostrom, 2010).

\section{Differences in cacao yield}

The VPC value (0.1786) indicates that approximately $18 \%$ of the variance in cacao yield in Chiapas and Tabasco could be attributed to differences between municipalities. This suggests that the variance between yields in each one of the observations is high.

Results from the comparison test of the null models of the level 1 and multilevel null model $(L R=24.71)$ show that there are differences in cacao yields between municipalities. Ho is rejected when 5\% $(\alpha=0.05)$ of distribution $\chi^{2}$ with $1 d f=3.84$; there is therefore evidence that the municipality variable affects cacao yield. This indicates that a multilevel model is preferable to a simple regression model to analyze this type of data. The joint mean of cacao yield was estimated as $380 \mathrm{~kg}$ $\mathrm{ha}^{-1}$; therefore, the estimated mean for any municipality $j$ was $380 \mathrm{~kg} \mathrm{ha}^{-1}+\mu_{\mathrm{oj}}$, which is the estimated residual for municipality $j$ (Table 2). This coincides with results reported by OEIDRUS (2013) for the differences between 
Table 2. Estimated cacao yield for different municipalities.

\begin{tabular}{llcc}
\hline State & Municipality & Estimated residual & Estimated mean \\
\hline \multirow{5}{*}{ Tabasco } & Comalcalco & 383.99 & 754.78 \\
& Huimanguillo & 234.60 & 605.39 \\
& Cunduacán & 150.71 & 521.50 \\
& Jalpa de Méndez & 145.52 & 516.31 \\
& Cárdenas & -24.65 & 346.14 \\
& Paraíso & -25.40 & 345.39 \\
\hline Huehuetán & -74.73 & 296.06 \\
\multirow{5}{*}{ Chiapas } & Pichucalco & -105.96 & 264.83 \\
& Villa Comaltitan & -130.25 & 240.54 \\
& Ostuacán & -163.81 & 206.98 \\
& Tuzantán & -168.00 & 202.79 \\
& Tuxtla Chico & -222.03 & 148.76
\end{tabular}

*The estimated mean is the result of the difference between the estimate from the null multilevel model (Table 3 ) and the estimated residual for each municipality.

yields at a municipal level, Tendencies in yield levels in the municipalities of Tabasco coincide with the results of this study, but statistics for the state of Chiapas present different results.

Data shown in Table 2 indicate two important findings: i) municipalities present differences in yield, which reflect the diversity of factors (climate, management practices, incidence of $\mathrm{MO}$ ) that can affect cacao production; and ii) municipalities in Tabasco have higher estimated mean yields than those in Chiapas. This result concurs with Díaz-José et al. (2013a), who used an econometric model to find that the decrease in cacao yield per unit area in Chiapas is greater than in Tabasco.

\section{Cacao yield alteration}

Table 3 shows the results of the fixed multilevel model for variables that affect cacao yield. The sample mean of alteration caused by MO in Mexico is $39 \%$. In the multilevel fixed model, $\beta_{0}$ can be interpreted as the predicted yield index for producers who have that degree of alteration. For any of the municipalities, increasing MO incidence will reduce cacao yields $\left(\beta_{1}\right)$. These results support Krauss et al. (2010) with regard to yield levels affected by MO.

Relative humidity is directly related to the amount of water available in the soil. Results show that yield increases with high relative humidity $\left(\beta_{2}\right)$. This concurs with Balasimha et al. (1991), who mention that prolonged

Table 3. Multilevel model for the purposes of cacao yield.

\begin{tabular}{|c|c|c|c|}
\hline Parameter & Null & Null Model & $\begin{array}{c}\text { Random } \\
\text { Intercept Mode }\end{array}$ \\
\hline \multicolumn{4}{|l|}{ Coefficients } \\
\hline$\beta_{0}$ & $478.26(39.41)^{1}$ & $380.79(75.39)^{1}$ & $396.08(232.3)^{1}$ \\
\hline$\beta_{1}$ (Moniliasis) & & & $-133.43(36.8)^{1}$ \\
\hline$\beta_{2}$ (Relative humidity) & & & $250.65(130.1)^{1}$ \\
\hline$\beta_{3}$ (Crop management) & & & $47.44(28.7)^{1}$ \\
\hline$\beta_{4}$ (Age of plantation) & & & $-2.50(2.79)$ \\
\hline$\beta_{5}$ (Area) & & & $-64.87(25.2)^{1}$ \\
\hline \multicolumn{4}{|l|}{ Components of variance } \\
\hline$\sigma_{\mathrm{u} 0}^{2}$ & & 46804 (27 494) & $21009(12959.0)$ \\
\hline$\sigma^{2} \mathrm{e}$ & & $215140(23940)$ & $185426(20805.7)$ \\
\hline LR (Log likelihood) & -1326.35 & -1315.26 & $-1299.98^{*}$ \\
\hline
\end{tabular}

${ }^{1} p<0.05$.

LR: Likelihood ratio test. ${ }^{*}$ LR test vs. linear regression: $\operatorname{chibar}^{2}(01)=9.95$ Prob $\geq$ chibar $^{2}=0.0008$ dry periods can affect the physiological process which reduces cacao production. In the same way, Rada et al. (2005) mention that micro-climatic characteristics, such as relative humidity and air temperature, significantly affect stomatal conductance that conditions yield. However, when interpreting relative humidity and yield relationships, precautions should be taken because high levels of relative humidity induce diseases caused by fungi.

A higher index of crop management practices $\left(\beta_{3}\right)$ increases yield. Practices such as weed control, drain maintenance, fertilization, pesticide application to control plagues and diseases improve plantation conditions and permit higher production. In this regard, Díaz-José et al. (2013b) found that low yields are associated with a low rate of good farming practices. It is therefore necessary to intensify farming practices to improve cocoa production.

The variable related to plantation age $\left(\beta_{4}\right)$ was not significant; this can be attributed to the fact that yield performance behaves as a normal curve with respect to tree age. Finally, for any municipality, increasing area by 1 ha would reduce the predicted yield $\left(\beta_{5}\right)$. Given that the current management of MO in Mexico is carried out through cultural practices and since cacao prices are low, increasing plantation area requires adequate management, which entails increased costs and losses for the producer. These results coincide with Fowler et al. (1956), who found a highly significant negative correlation between yield and cacoa plantation area and attributed this behavior to the fact that growth rate management in smaller cacao plantations is better. In addition, PhillipsMora et al. (2007) mention that the frequency and costs of cultural practices are the main factors that restrict the adequate management of cacao plantations.

When calculating confidence intervals from the standard deviation between municipalities, it was found that producers who reside in municipalities with the lowest yields obtain up to $111 \mathrm{~kg} \mathrm{ha}^{-1}$, while those who are in the municipalities with the highest yields obtain production greater than $680 \mathrm{~kg} \mathrm{ha}^{-1}$ (this interval was estimated as $\left.\beta_{0} \pm\left[1.96 \times \sqrt{ } \sigma^{2} \mu_{0}\right]=[111.99,680.17]\right)$.

Results suggest that intervention strategies to promote cacao production should consider two important scenarios: i) zones where there is an abandonment of the activity, as evidenced by the productive level of plantations, and where there is a need for rescue strategies of the activity; and ii) zones with productive potential and good yield where an increase in productivity should be promoted, as well as improving the quality of grains obtained. These points show the need to apply differentiated strategies based on the characteristics of each production region.

\section{Incidence of moniliasis and maintenance practices in plantations}

Results indicate that $\mathrm{MO}$ disease has a higher occurrence in Chiapas (60\%) than in Tabasco (48\%) (Table 4). 
Table 4. Alteration caused by moniliasis and plantation management practices

\begin{tabular}{lc}
\hline Parameter & Random multilevel \\
\hline Coefficients & \\
$\beta_{0}$ & $0.605(0.066)^{1}$ \\
$\beta_{1}$ (state) & $-0.1226(0.044)^{1}$ \\
$\beta_{2}$ (index of practices) & $-0.0464(0.019)^{1}$ \\
Random component municipality level & \\
$\sigma^{2} \mathrm{u}$ (variance of intercept) & $0.025(0.018)$ \\
$\sigma_{\mathrm{u} 1}^{2}$ (variance of index of practices) & $0.006(0.003)$ \\
$\sigma_{\mathrm{u} 01}$ (covariance intercept - index of practices) & $-0.012(0.007)$ \\
Random component level producer & \\
$\sigma^{2} \mathrm{e}$ & $0.034(0.004)$ \\
Log likelihood & 37.83 \\
\hline
\end{tabular}

${ }^{1} p<0.05$.

*Dependent variable: Alteration caused by moniliasis. $\beta_{l}$ State: Chiapas $X=$ 0 , Tabasco $X=1$.

Phillips-Mora et al. (2007) mention that MO is able to thrive in a wide range of environmental conditions from sea level to over $1000 \mathrm{~m}$ a.s.l. and from dry to humid zones.

For the average municipality, a decrease caused by MO incidence is predicted as 0.046 points for each maintenance practice carried out on the plantations (formation pruning, maintenance, rehabilitation, and removal of diseased fruits). This proves that plantations with good management tend to exhibit lower MO incidence; this is shown by Torres de la Cruz et al. (2011) when comparing management strategies for $\mathrm{MO}$ in cacao. At the experimental level, these practices have had good results; however, this study shows that there are also positive results at field level.

In terms of residuals for intercept and slope as the result of the multilevel random model, it can be seen that MO incidence decreases with a higher level of crop management practices carried out in cacao plantations (Figure 2). This leads to the identification of four groups of municipalities: i) those that perform a higher number of management practices in plantations and have low MO incidence; ii) municipalities that in spite of performing

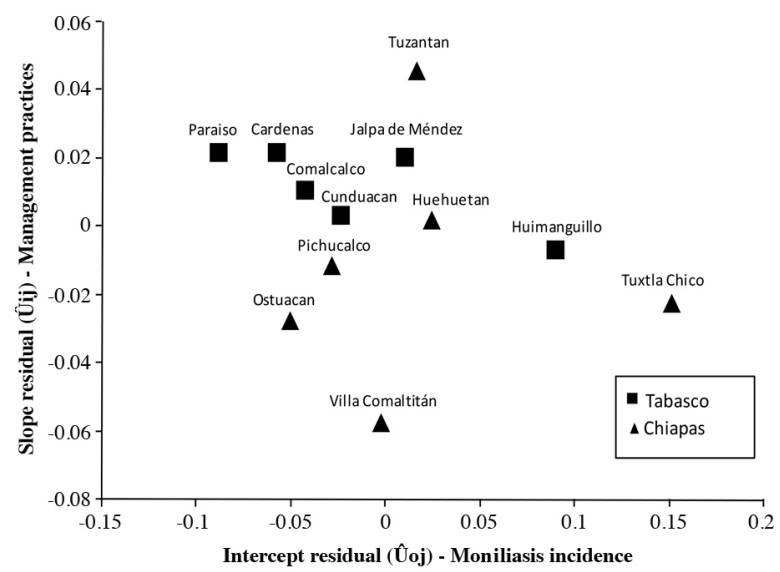

Note: Each point represents a municipality.

Figure 2. Estimated intercept and slope residuals for the relationship between crop management practices and moniliasis incidence. an important number of management practices have a significant incidence of the pathogen; iii) municipalities with a low index of maintenance practices that have high MO incidence; and iv) municipalities that perform few management practices and have low incidence of the disease. It is interesting that the latter are concentrated in the northern region of the state of Chiapas.

The first group of municipalities has a behavior that corresponds to studies reporting that the best strategy for MO control is based on intensifying crop management practices (Porras et al., 1990; Leach et al., 2002; Evans, 2007; Torres de la Cruz et al., 2011). In the second group, it is evident that plantation management has not been effective although efforts have been made to counteract the disease; this can be the result of poorly applying the practices, scarcity of information about the biological effects of the pathogen, or agro-climatic variables that promote the development of the disease.

The third group shows that the abandonment of plantations increases MO incidence. According to Krauss et al. (2010), after MO appears it can reduce yield up to $80 \%$ in only a few years. The fourth group has a different behavior from what is logical for this analysis; in the case of two municipalities in Chiapas (Pichucalco and Ostuacan), low incidence can be attributed to the geographic location and different climatic conditions, while Villa Comaltitan exhibits the general mean of MO incidence obtained in this study.

Leach et al. (2002) mention that cacao cultivation is economically viable in spite of the presence of $\mathrm{MO}$; however, it is necessary to provide plantation maintenance by removing diseased fruits to prevent dispersion and accumulation of the disease in the plots.

\section{CONCLUSIONS}

Cacao cultivation in Mexico exhibits structural characteristics (plantation area, age of producers, plantation age, and moniliasis incidence) that condition production and yield. There are marked differences in yields between the states of Tabasco and Chiapas, as well as between their municipalities. Alteration caused by moniliasis is also differentially reproduced and is approximately $40 \%$ in the cacao plantations, which largely reduces yields; however, a higher number of management practices can increase plantation yields and reduce the effect of moniliasis. Moniliasis has become a negative externality of cacao production in Mexico since a plot without maintenance disperses the disease to other plantations, which is why sanitation regulatory instruments are required. This suggests the need to apply policies to promote cacao production that take into account technical and social aspects, that is, equipment and training for pruning and management, strategies for plantation renewal, information systems for decision making, and political instruments that promote collective 
action. These strategies should be differentiated according to local producer conditions. Future research should include other variables, such as geographic and soil references, to determine conditions that foster moniliasis development.

\section{ACKNOWLEDGEMENTS}

The authors would like to acknowledge the Instituto Interamericano de Cooperación para la Agricultura (IICA-México) for the information provided to carry out this study, as well as two anonymous reviewers for their helpful comments.

\section{LITERATURE CITED}

Adesimi, A.A. 1984. 'Normal' yields by tree ages as a basis for tree crop insurance scheme in Nigeria. Agricultural Administration 15(4):197-203. doi:10.1016/0309-586X(84)90084-0

Balasimha, D., E.V. Daniel, and P. Bhat. 1991. Influence of environmental factors on photosynthesis in cocoa trees Agricultural and Forest Meteorology 55(1-2):15-21.

Córdova, V., M. Sánchez, N. Estrella, A. Macías, E. Sandoval, T. Martínez, et al. 2001. Factores que afectan la producción de cacao (Theobroma cacao L.) en el ejido Francisco I Madero del Plan Chontalpa, Tabasco, México. Universidad y Ciencia 17:93-100.

Cuervo-Parra, J.A., M. Ramírez-Suero, V. Sánchez-López, and M. Ramírez-Lepe. 2011. Antagonistic effect of Trichoderma harzianum VSL291 on phytopathogenic fungi isolated from cocoa (Theobroma cacao L.) fruits. African Journal of Biotechnology 10:10657-10663.

De Leeuw, J., and E. Meijer (eds.) 2008. Introduction to multilevel analysis. p. 1-75. Handbook of multilevel analysis. Springer, New York, USA.

Díaz-José, O., J. Aguilar-Ávila, R. Rendón-Medel, and V.H. Santoyo-Cortés. 2013a. Current state of and perspectives on cocoa production in Mexico. Ciencia e Investigación Agraria 40:279289. doi:10.4067/rcia.v40i2.1095.

Díaz-José, J., M. Muñoz, y E. Martínez 2011. Dinámica de la propiedad social en México. p. 239-264. In Vargas, G.A., V.H. Palacio, G. Almaguer, and M. Muñoz (eds.) El campo mexicano: 1970-2007. Un análisis a partir de los censos agrícolas, ganaderos y ejidales. Mundi-Prensa-Universidad Autónoma Chapingo/ CIESTAAM, Chapingo, México.

Díaz-José, O., V.H. Porras, y J. Aguilar-Ávila. 2013b. El cacao (Theobroma cacao L.): avances y retos en la gestión de la innovación. 136 p. Colección Trópico Húmedo, Universidad Autónoma Chapingo, Chapingo México.

Diederen, P., H. van Meijl, A. Wolters, and K. Bijak. 2003. Innovation adoption in agriculture: innovators, early adopters and laggards. Cahiers d'Économie et Sociologie Rurales 67:30-50.

Eastwood, R., M. Lipton, and A. Newell. 2009. Small farms. p. 3323-3397. In Pingali, P., and R. Evenson (eds.) Handbook of Agricultural Economics. North Holland Publishing, Amsterdam, Netherlands.

Edwin, J., and W.A. Masters. 2005. Genetic improvement and cocoa yields in Ghana. Experimental Agriculture 41:491-503. doi:10.1017/S0014479705002887.

Evans, H.C. 2007. Cacao diseases- The trilogy revisited. Phytopathology 97:1640-1643. doi:10.1094/phyto-97-12-1640.

Fowler, L.R., R. Desrosiers, and H. Hopp. 1956. Evaluation of certain factors affecting the yield of cacao in Ecuador. Ecology $37: 75-81$.
Gershon, F., R.E. Just, and D. Zilberman. 1985. Adoption of agricultural innovations in developing countries: A survey. Economic Development and Cultural Change 33:255-298 doi: $10.2307 / 1153228$.

González, V. 2005. Cacao en México: competitividad y medio ambiente con alianzas. United States Agency International Development (USAID), Washington D.C., USA.

Hernández-Gómez, E., M. López-Navarrete, E. Garrido-Ramírez, J. Solís-Bonilla, A. Zamarripa-Colmenero, C. Avendaño-Arrazate, et al. 2012. La moniliasis (Moniliophthora roreri Cif \& Par) del cacao: búsqueda de estrategias de manejo. Agroproductividad 5:3-8.

Hox, J. 2002. Multilevel analysis. Techniques and applications. p 299. Lawrence Erlbaum Associates, Mahwah, New Jersey, USA.

Krauss, U.,E. Hidalgo, R. Bateman, V.Adonijah, C.Arroyo, J. García et al. 2010. Improving the formulation and timing of application of endophytic biocontrol and chemical agents against frosty pod rot (Moniliophthora roreri) in cocoa (Theobroma cacao). Biological Control 54:230-240. doi:10.1016/j.biocontrol.2010.05.011

Leach, A.W., J.D. Mumford, and U. Krauss. 2002. Modelling Moniliophthora roreri in Costa Rica. Crop Protection 21:317-326. doi:10.1016/003355398555720.

Nyemeck, J.B., J. Gockowski, and G.B. Nkamleu. 2007. The role of credit access in improving cocoa production in West African countries. p. 215-224. Proceedings Second International Conference African Association of Agricultural Economists (AAAE), Accra, Ghana. 20-22 August 2007. AAAE, Nairobi, Kenya.

OEIDRUS. 2013. Estadistica básica del Sistema de Información para el Desarrollo Rural Sustentable. Servicio de Información Agroalimentaria y Pesquera, Secretaría de Agricultura, Ganadería Desarrollo Rural, Pesca y Alimentación (SAGARPA), México D.F. Available at http://www.oeidrus-chiapas.gob.mx/ (accessed July 2014).

Ogata, N. 2007. El cacao. Comisión Nacional de Biodiversidad (CONABIO). Biodiversitas 72:1-5.

Ostrom, E. 2010. Analyzing collective action. Agricultural Economics 41:155-166. doi:10.1111/j.1574-0862.2010.00497.x.

Phillips-Mora, W., M.C. Aime, and M.J. Wilkinson. 2007. Biodiversity and biogeography of the cacao (Theobroma cacao) pathogen Moniliophthora roreri in tropical America. Plant Pathology 56:911-922. doi:10.1111/j.1365-3059.2007.01646.x.

Phillips-Mora, W., A. Coutiño, C.F. Ortiz, A.P. López, J. Hernández, and M.C.Aime. 2006. First report of Moniliophthora roreri causing frosty pod rot (moniliasis disease) of cocoa in Mexico. Plant Pathology 55:584-584. doi:10.1111/j.1365-3059.2006.01418.x.

Porras, V.H., C.A. Cruz, y J.J. Galindo. 1990. Manejo integrado de la mazorca negra y la moniliasis del cacao en el Trópico Húmedo Bajo de Costa Rica. Turrialba 40:238-245.

Rada, F., R.E. Jaimez, C. García-Núñez, A. Azócar, and M.E Ramírez. 2005. Water relations and gas exchange in Theobroma cacao var. Guasare under periods of water deficit. Revista de la Facultad de Agronomía 22:112-120.

Ryan, D., G.A. Bright, and E. Somarriba. 2009. Damage and yield change in cocoa crops due to harvesting of timber shade trees in Talamanca, Costa Rica. Agroforestry Systems 77:97-106. doi:10.1007/s10457-009-9222-1.

SIAP. 2012. Producción anual de cacao en México. Servicio de Información Agroalimentaria y Pesquera (SIAP)-Secretaría de Agricultura, Ganadería, Desarrollo Rural, Pesca y Alimentación (SAGARPA), México D.F.

Sistema de Información Arancelaria. 2012. Capítulo 18. Cacao y sus preparaciones. Sistema de Información Arancelaria, Secretaría de Economía, México D.F.

Snijders, T. 2011. Multilevel analysis. p. 879-882. In M. Lovric (ed.) International encyclopedia of statistical science. Springer, Berlin Heidelberg, Germany. 
Steele, F. 2008. Module 5: Introduction to multilevel modelling. LEMMA VLE, University of Bristol, Centre for Multilevel Modelling. Available at http://www.bristol.ac.uk/cmm/learning/ module-samples/5-r-sample.pdf (accessed April 2013).

ten Hoopen, G.M., P. Deberdt, M. Mbenoun, and C. Cilas. 2012. Modelling cacao pod growth: implications for disease control. Annals of Applied Biology 160:260-272. doi:10.1111/j.17447348.2012.00539.x.

Torres de la Cruz, M., C.F. Ortiz, D. Téliz, A. Mora, and C. Nava. 2011. Temporal progress and integrated management of frosty prod rot (Moniliophthora roreri) of cocoa in Tabasco, Mexico. Journal of Plant Pathology 93:31-36.
Zamarripa-Colmenero, A., J.L. Solís-Bonilla, y E. HernándezGómez. 2011. Comportamiento agronómico de descendencias híbridas de cacao con resistencia a moniliasis. Folleto Técnico $\mathrm{N}^{\circ} 27.39$ p. Campo Experimental Rosario, Izapa (ed.) INIFAP, Tuxtla Chico, Chiapas, México.

Zuidema, P.A., P.A. Leffelaar, W. Gerritsma, L. Mommer, and N.P.R. Anten. 2005. A physiological production model for cocoa (Theobroma cacao): Model presentation, validation and application. Agricultural Systems 84:195-225. doi:10.1016/j. agsy.2004.06.015. 